INDEPENDENT JOURNAL OF MANAGEMENT \& PRODUCTION (IJM\&P)

http://www.ijmp.jor.br

v. 12, n. 8, November-December 2021

ISSN: 2236-269X

DOI: 10.14807/ijmp.v12i8.1465

\title{
RISK MANAGEMENT PROCESS AND APPROACHES FOR COVID- 19 BY INDIAN EDUCATIONAL INSTITUTIONS
}

\author{
Ashraf Imam \\ Faculty of Business Studies, Arab Open University, Saudi Arabia \\ E-mail: imamashraf12345@gmail.com
}

Submission: $11 / 10 / 2020$

Accept: 1/19/2021

\section{ABSTRACT}

The novel and ongoing coronavirus (COVID-19) epidemic in India has had a phenomenal effect on India's financial, educational system and community development. It effects the overall education system in India but the Indian educational institutions have made substantial contributions and taking proper steps to minimize the effects of this virus. Its only made possible by the contributions have been made primarily by medical and emergency management, counselling for mental health, control on people's movement and innovation in Emergency remote teaching (ERT). In what manner to tackle these risks and emergency problems, this paper reviewed and presented all the situations, highlighted the risk management process and plan of Indian educational institutions from university to school level institutions and proposes some approaches for the solutions of community dissemination.

Keywords: COVID-19; Epidemic; Education system; Indian educational institutions; risk management process; Emergency remote teaching (ERT), Information technology

JEL Classification: G32, C73 
DOI: 10.14807/ijmp.v12i8.1465

\section{INTRODUCTION}

Chinese government informed WHO Regional office based at China on December 31st, 2019 about the cases of pneumonia which detected in Wuhan City and till that time no cause was detected and on January 7th, 2020, the Chinese authorities announced they had identified a new virus that causes these cases which we all known by its name called as Coronaviruses $(\mathrm{CoV})$ or COVID-19 that is mainly transmitted through droplets generated when an infected person coughs, sneezes, or exhales (Who, 2020; Who, 2020a).

These droplets are too heavy to hang in the air, and quickly fall on floors or surfaces and people will be infected by breathing in this virus if you are within close proximity of someone who has COVID-19, or by touching a contaminated surface and then your eyes, nose or mouth. India reported the first confirmed case of the coronavirus infection on 30 January 2020 in the state of Kerala due to infected person had a travel history from Wuhan, China (Unnithan, 2020).

There are number of studies conducted on managing the risk but how to deal with the COVID-19 and their consequences on different industry, we found few of them due to the new concern of the society related to this virus and there are studies which mostly associated with enterprise risk management (ERM) and their implementation like the study conducted by Beasley et. al., (2005) in which they analyses the factors associated with the stage of ERM implementation at a variety of US and international organizations and found that the stage of ERM implementation to be positively related to the presence of a chief risk officer, board independence, CEO and CFO apparent support for ERM (Jabbour, 2011).

Enterprise risk management creates value for shareholders and have practical issues that arise in the implementation of enterprise risk management and also troubling risksnotably, reputational and strategic risks-are the most difficult to quantify (Nocco and Stulz (2006). Abdul (2007) studied that the constant backing from top authorities, external proficiency and organization at more advanced phase in larger entities lead to ERM effective and institutions must understand that organizational precise tasks to creating a risk managing outline are several and also substantial addressed should be given to the cultural issues (Institute of Risk Management - IRM, 2012).

In educational institution's plans where exercise is ongoing and established, assumptions cannot be made about the understanding of the roles, risks, and benefits involved in such relationships among students, mentors, and instructors and all have different 
INDEPENDENT JOURNAL OF MANAGEMENT \& PRODUCTION (IJM\&P)

http://www.ijmp.jor.br

v. 12, n. 8, November-December 2021

ISSN: 2236-269X

DOI: 10.14807/ijmp.v12i8.1465

perspectives about the risk (Colvin \& Ashman, 2010). There are behavioral and mental health issues challenge institutions of higher education with difficult decisions around response and a primary way of responding to these challenges is through the formation of campus assessment teams (Eells \& Rockland, 2010).

According to Kinman and Court (2010) the extent to which higher education institutions in the United Kingdom meet the minimum standards recommended by the Health and Safety Executive (HSE) for the risk management of work-related stressors.

Managing risk and exercised by the banks, specifically, commercial banks in Pakistan revealed a substantial change in the application of risk management facets among the public sector commercial banks and local private banks and still there is a need for commercial banks to develop training courses custom-made needs of banking personnel in risk management unit (Shafiq \& Nasr, 2010).

According to Gupta (2011) the current status of risk management in Indian companies is the lack of adoption of integrated approach to risk management and shows that effective risk management can improve organizational performance but adequate infrastructure is not available in companies for implementing EWRM (Manab et. al.,2012). The methodical method towards the understanding the classification of the success dimension in risk management process is important for re-enforcing effective risk management practices (Yaraghi \& Langhe, 2011).

Abdullah et. al., (2012) studied the available researches regarding the basic reasons that effect the application of ERM in organization and influence to professional performance while handling risks to continue in this competitive world and concluded that the ERM applications can be seen as less due to the lack of familiarity on this subject among entities in organization.

Risk management process in the other industry their and reports findings the status of risks, their existing management techniques, the existing status of risk management systems of the organizations, and blockades to effective risk management from the outlook of main stakeholders. According to Choudhary and Iqbal (2013) discloses that financial, economic and excellence factors are the most important risks, the industry generally tries to evade or transfer these risks and the lack of process for joint risk management by the parties.

According to Toma et. al. (2014), the risk management is no more restricted to any specific sector and now it's also the part of higher education institutions. Although, the risk management process in academia appear to be knowingly less established as compared to the 
DOI: 10.14807/ijmp.v12i8.1465

other industry. Risks can distress institutional facilities to function and disturb the strategic objectives.

Mustapha and Adnan (2015) attempted to discovered the ERM implementation in Malaysian construction companies and the results suggested that the awareness and understanding of ERM concept by employees is the main factor in ensuring a successful ERM implementation. Contribution from all level of employees (Harvard Business Review (HBR), 2014) especially the commitment from the top management is crucial to ensure its successful implementation and continuous activities such as follow up monitoring the risk management exercises are important in managing risks effectively.

Fraser and Simkins (2016), this study found the challenges of companies when implementing ERM and offered Hydro One is an excellent organization to benchmark for ERM best practices for firms struggling with the concepts and execution. Lastly, we found only few studies which are based on risk management during COVID-19 situation, firstly study conducted by Yue et al., (2020) where they focused from the outlooks of initial cautioning and identification of risk, risk monitoring, and analysis, as well as risk management and proposes the solutions which include institutional cooperation whether it is educational or industrial institutions, and to advise national and international policy-makers regarding the precautionary measures.

Liu and Saif (2020) in which paper analyses that the condition has drawn international consideration, including from the virology community and they have faith in that augmented transparency on coronavirus reportage and data sharing with international colleagues are vital for reduction of spreading of this newly emerging virus to other parts of the world. In context of academic institutions study presented by Wang et. al., (2020) highlighted the Chinese universities for their significant contributions towards the emergency management and the problems and challenges and proposes the resolutions for community broadcasting, including problems related to well-being, reserve research, expert support, constructive statement, and classified information-based instruction.

Concluding remarks that at this point, there is little studies and research on risk management during COVID-19 situations or any pandemic situation by educational institutions and especially in context of India we found no research or studies on this particular topic. So, the aim of this present study is to highlights the conditions of risk management process implementation by the Indian educational institutions during the COVID-19 for the benefit of 
INDEPENDENT JOURNAL OF MANAGEMENT \& PRODUCTION (IJM\&P)

http://www.ijmp.jor.br

v. 12, n. 8, November-December 2021

ISSN: 2236-269X

DOI: 10.14807/ijmp.v12i8.1465

the society safety and security and what are the possible approaches taken by Indian educational institutions for COVID-19. Through this paper we tried to cover a wide range of Indian educational institutions like universities, colleges, institute and schools.

\section{COVID 19 AND INDIAN EDUCATIONAL INSTITUTIONS}

All educational institutions globally have temporarily closed to reduces the outbreak of the COVID-19. These nationwide shut down are impacting nearly all the world's student fraternity. These nationwide shut down effect not only students, teachers, and families but also economy and of course the societies around the world. World Health Organization (WHO) on February 11, 2020 named a pandemic caused by the novel coronavirus SARS-CoV-2 as COVID-19. COVID-19 is an abbreviation that stands for coronavirus disease of 2019 (Vergnaud, 2020).

As per the UNICEF monitoring, 153 countries are currently implementing nationwide closures and 24 are implementing local closures, impacting about 98.6 percent of the world's student population and 10 countries' schools are currently open (Wikipedia contributors, 2020). Around 1.2 billion students and learners across the planet are affected by educational institutions closures due to the COVID-19 outbreak (UNESCO, 2020). Data of affected learners from India is shown by the table 1 given below.

Table 1: Affected Learners from India

\begin{tabular}{|l|l|l|l|l|}
\hline \multicolumn{5}{|l|}{ India } \\
\hline Affected Learners & $320,713,810$ & \multicolumn{3}{l|}{} \\
\hline Total Females & $158,158,233$ \\
\hline Total Males & $162,555,577$ \\
\hline $\begin{array}{l}\text { Type of Educational } \\
\text { Institution }\end{array}$ & Pre-Primary & Primary & Secondary & Tertiary \\
\hline Females & $4,557,249$ & $72,877,621$ & $63,983,677$ & $16,739,686$ \\
\hline Males & $5,447,169$ & $70,349,806$ & $69,160,694$ & $17,597,908$ \\
\hline Total & $10,004,418$ & $143,227,427$ & $133,144,371$ & $34,337,594$ \\
\hline
\end{tabular}

Source: Reprinted from UNESCO (25 May, 2020)

UNESCO is supporting countries in their efforts to ease the instantaneous effect of educational institution's closures, particularly for marginalized and deprived communities, and to enable them for continuity of education through emergency remote teaching and learning. UNESCO suggested the use of online learning programs and open educational applications and platforms that educational institutions and teachers can use to reach learners remotely and limit the disruption of education that's why in present scenario researcher called this type of teaching and learning as emergency remote teaching (Muller \& Goldenberg, 2020; Inside Higher Ed IHE, 2020). 
DOI: 10.14807/ijmp.v12i8.1465

\section{RISK AND RISK MANAGEMENT PROCESS AT INDIAN EDUCATIONAL INSTITUTIONS}

\subsection{Overview about Risk Management Process}

When risk in educational institutions is the topic, what we receive in the news or read online is COVID-19, the outbreak of coronavirus which already spread throughout the world (Gutiérrez, 2020). While these types of epidemic situations are very severe in nature and it will spread quickly as compared to the other infectious diseases.

In educational institutions it is considered to be very important because in educational institutions there were heavily interactions among teacher and students and between students also. Let's talk about the risk at educational institutions but before going forward we should know first the exact meaning of the word 'risk'. The Oxford English Dictionary definition of risk is as follows: 'a chance or possibilities of danger, loss, injury or other adverse consequences', and the definition of at risk is 'exposed to danger'. In this context, risk is used to signify negative consequences (Hopkin, 2018).

There are some risks which could impact any educational institutional objectives and goals (Ruzic-Dimitrijevic \& Dakic, 2014). For the better understanding we categorize these risks under the following areas like academic risk, teaching risk, compliance risk, financial risk, strategic risk, operational risk, technological risk, research risk and reputational risk and epidemic risk (Helsloot \& Jong, 2006; Raanan, 2008; Prudente Tixteco et al., 2017; Deloitte, 2018; Safetrac, 2019; Shewey, 2019). In reality these are the possible risks at educational institutions and who are at risk \& will be affected and what are the consequences and its effects is showing by the table 2 .

Table 2: Risks of Educational Institutions

\begin{tabular}{|c|c|c|}
\hline Risks & Affected & Effects \\
\hline Fire \& Explosion & \multirow{5}{*}{$\begin{array}{l}\text { People, Society, Property and } \\
\text { other infrastructure of the } \\
\text { institutions }\end{array}$} & \multirow{5}{*}{$\begin{array}{l}\text { Casualties, Property Damage, Institutions } \\
\text { Operations, Financial Loss, Reputation } \\
\text { loss, fail to restore confidence of students } \\
\text { towards the institutions, Fines \& } \\
\text { Penalties, Lawsuits, Environmental } \\
\text { contaminations }\end{array}$} \\
\hline $\begin{array}{l}\text { Disturbance created by insider or } \\
\text { outsider within the Institutions }\end{array}$ & & \\
\hline $\begin{array}{l}\text { Natural Hazards like heavy rain, } \\
\text { floods, earthquake etc. }\end{array}$ & & \\
\hline $\begin{array}{l}\text { Mechanical breakdown like total } \\
\text { electricity faults or System Down } \\
\text { by Cyber attack }\end{array}$ & & \\
\hline $\begin{array}{l}\text { Pandemic Diseases like Ebola, } \\
\text { Dengue, Swine Flu and COVID- } \\
19\end{array}$ & & \\
\hline
\end{tabular}


INDEPENDENT JOURNAL OF MANAGEMENT \& PRODUCTION (IJM\&P)

http://www.ijmp.jor.br

v. 12, n. 8, November-December 2021

ISSN: 2236-269X

DOI: 10.14807/ijmp.v12i8.1465

\subsection{Risk management process at Indian Educational Institutions}

Those institutions and organizations giving high priority to the risk management actions are growing because they are doing much better in the case of risks and due to these risks, they are active towards any mishappening in the environment.

In India, government or regulatory bodies like MHRD, UGC \& AICTE are conscious of cumulative regulations regarding safety and health, compelling educational institutions to put more focus on risk management framework.

But the attitude of competent authorities of educational organization towards the risks related to their organizations are inappropriate and it's not the good sign and ultimately COVID-19 outbreak continue to increase. To fight and ease risks, institutions boards should focus on common approach towards the risk management process that includes identification of the risks, analyzing the risks, evaluating risks, implementation of risk management framework and monitoring their efforts.

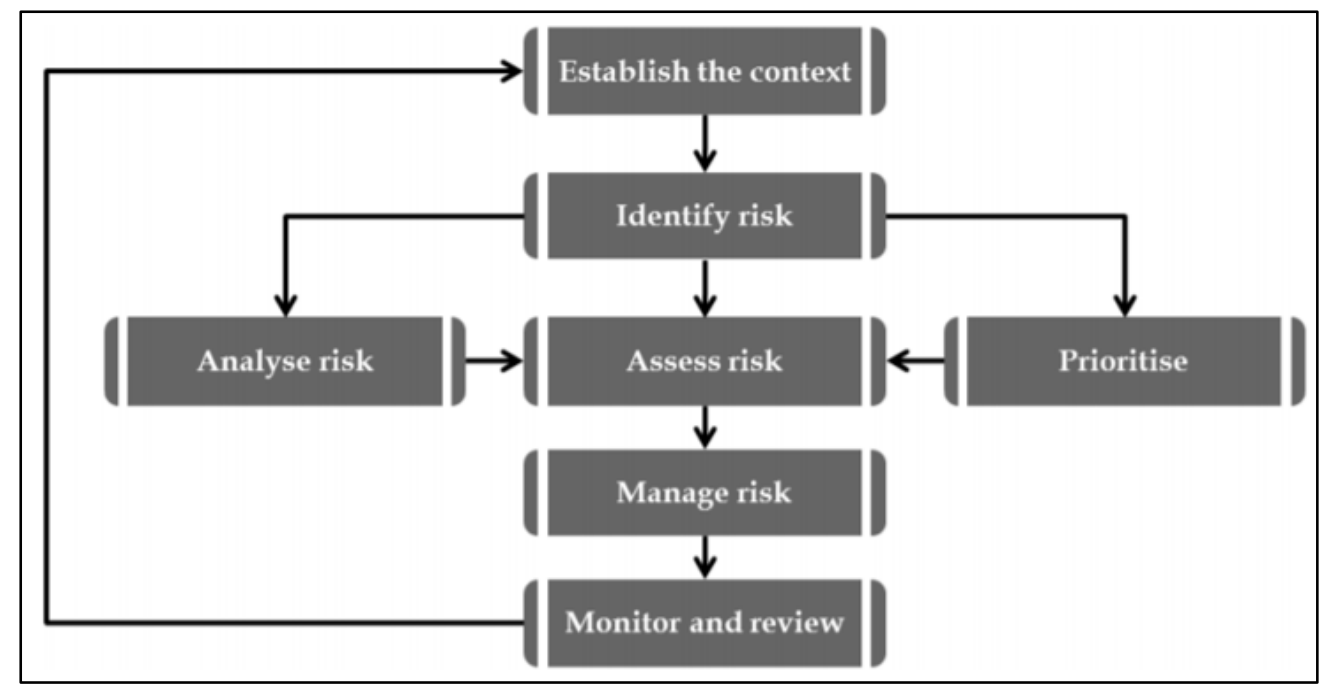

Figure 1: Risk Management Process Steps

Source: ISO Standard Guidelines

\subsubsection{Risk Management Process Steps}

- Identification of the risk

Most important and initial step in risk management process is to identifying the possible risks, so educational institutions first need to see and understand the issues that drive various risks due to COVID-19. Educational Institutions faces multiples risks including academic functioning risk, economic risk, strategic risk and status or brand image risk. 
DOI: 10.14807/ijmp.v12i8.1465

There are several issues related to COVID risk which need to consider by competent authorities of the institutions like during COVID situation.

Like competition with other educational institutions going to be increases, use of better technology for online learning program due to lack of personal contact with the students, methods of obtaining degrees as we have seen that some of the universities organizes digital graduation ceremony for their passing out graduates. Also, educational institutions showing decreasing trends in their student enrollment due to the COVID-19 situation.

In handling these possible risks due to attack of corona virus, educational authorities need to evaluate their financial position which cost them high due recent changes in the education delivery pattern which is now online or we can almost everything online now and for this pattern we are heavily depends on updated information technology and upgraded available software for online programs and activities which in long run hamper the institution's philosophy, goals and objectives if properly not managed by the competent authorities of the educational institutions.

These all consider as academic functional risks, also there is research risk for example the institutions that have a research-oriented institution must have risks related to managing toxic chemicals and materials due to sudden closures of laboratory which affected by COVID situation lockdown. Another we have seen the lockdown situation especially long-term lockdown which ultimately affects status of the educational institutions and significantly impact enrollment, finances and, ultimately, the sustainability of the institution and this is what we called as status or brand image risk.

- Analyzing Risks

The most common tool for managing risk is to prepare risk management matrix in which we classify to the possible risks according the impacts as low, medium, high or extreme. In the COVID-19 situation, risk is high for all categories whether it is about academic session or students, teaching staffs or non-teaching staffs. So, it's impact on each and every one is high but there is slightly difference of impact between them, corona virus risk is high for teachers and students because of close interaction during their lectures if it is not online.

As compared to teaching fraternity non-teaching staffs have some lower risk due to non-interaction with the other peoples in the organization. Due to COVID-19, educational institutions putting all the academic activities on digital platform and using online mode so ultimately its impact is high on academic development. 
DOI: 10.14807/ijmp.v12i8.1465

\section{- Evaluating Risks}

Institutional team can use the risk management matrix to take the next step which will helping them in evaluating the risks. In this stage they will score the risk on the basis of severity and chance of its occurring. This risk management matrix is also a helpful tool for listing ways to lessen each risk.

\section{- Implementation of Risk Management Process}

At each stages of risk management process, institutional risk management team members analyzing the institution's strategy, goals, and the condition of the site, including the property, students, resources, etc. The designated person for the risk management would develop a risk selection, which they can use to authenticate and rank risks as they emerge.

\section{- Monitor and Review the Risk Management Process}

In management process and implemented plan and to ensure this stage team will analyze their whole risk that all are contributing their part to protect themselves and to protect the institution from risk like COVID-19. An effective risk management process and plan requires institutional support and to take accountability for risk management with their team and senior administrators. The educational institutions authorities must show a continuous role in supervision and monitoring the risk management process and plan.

\section{APPROACHES FOR COVID 19 FROM INDIAN EDUCATIONAL INSTITUTIONS}

It is sole responsibility of the educational institutions for facilitating support for COVID-19 epidemic control. Recently we all are facing the new type of coronavirus COVID19 and every Indian educational institution have responded sensibly towards this epidemic. Although Indian populations is on second order in the list, Indian citizens taking care very sensibly towards this corona attack and following the lockdown and other precautionary measures to control this epidemic.

There are some cases in news media of mishandling but it's all negligible amount. We celebrated our festival at home and greeted each other's through the medium of electronic mode. Even the universities, colleges, institutes and schools all completed their exams and academic session through the mode of online session and it's a new and wonderful experiences for all and all we have learnt so many things due this corona virus lockdown. Currently, Indian 
DOI: 10.14807/ijmp.v12i8.1465

educational institutions performing their academic functions, and their sole character in terms of social services, scientific research and talent training developmental functions.

\subsection{People and Institutional Support}

Citizens from India and Non-Resident Indians (NRI) living abroad continuously contributing and showing their support to the PM Cares Fund for the fight against coronavirus. From the beginning of the epidemic and lockdown announcement by the government of India, educational institutions use their resources to set up their machinery for remote online teaching and other material support channels for the learners.

Educational institutional infrastructures and hotel rooms across the nation have been set aside for quarantining suspect patients, asymptomatic travelers or for accommodating and providing meals for the frontline staffs battling the Covid-19 outbreak (Chaturvedi, 2020). All these are people and institutions providing their support during this COVID-19 situation.

\subsection{Medical Staffs for Emergency and Researcher Support}

Medical Colleges from the Indian educational institutions whether they are from public or private institutions, they came forward to showing their support and handling the corona patients round the clock without break, this is another emergency support to the government by these institutions.

Also, they are working on the emergency research for finding out the vaccine for this COVID-19 and hopefully they will able to find out the best solutions. The scientist and researcher of Indian universities has provided robust methodical backing for the preparing of the coronavirus detection kit.

\subsection{Act as a Counselling and Social Therapy Services Centre for the Society}

With the more cases and frightening situation due to COVID-19 government emphasis more on prevention and control public transport system especially buses and trains to control frequent movements of the peoples from one place to another place. Lockdown is not the final solutions but it's required to control the epidemic from increasing but due to continuous lockdown peoples now have psychological problems and in order to fight with these side effects of the long term lockdown and fear of corona virus some of the educational institutions especially universities providing psychological and counselling services to the people for stabilizing the social conditions in the society. 
DOI: 10.14807/ijmp.v12i8.1465

Teaching fraternity especially from the sports background from the different educational institutions uploaded their videos of home exercise like yoga asana to help people in maintaining their mental and physical strength in improving their immune system.

\subsection{Pedagogical Change}

All educational institutions strictly following the orders of the government of India for closing the personal interaction of students and teaching community and many of them decided to go online and remote teaching for whole semester from February, 2020 to till now. Still some of them delaying the admission process for the new academic session 2020-2021.

All these postponements of the educational institutions helpful for the epidemic control. Indian universities have demonstrated outstanding creativity in compliant their social responsibilities, opening teaching platforms to society without charge, sharing high-quality course resources. Indian education system has also provided online learning resources to improve our knowledge without leaving homes which will ensuring that our studies are not seriously affected.

\section{CONCLUSION}

This review article shows that Indian educational institutions still do not usually have a unified policy on protection, safety and emergency management for any pandemic situation but struggling and coping with the current situation of COVID-19 with the best possible alternates. Within the institutions, there is a communication gap between different units of the institution especially related to risk management process and plan.

All stakeholders of the educational institutions have insufficient awareness about the different types of risks to which they and their educational environment are exposed. Also, institutions not sharing their practices in the managing the risk with the others. Their main concern and involvement only about the common types of risks which associated with educational settings are operational risk, financial risk, theft and intellectual property right risk etc.

Educational institutions still look to be relatively unaware of the pandemic risk particularly infectious disease risk like COVID-19 and less prepared to deal with these types of incidents. Now after this COVID-19 situation educational institutions focusing most of their attention on this risk. Efforts to control other risks which arises due to this COVID-19, such as academic loss, research loss, operational loss or even the financial losses also. Lastly, this 
INDEPENDENT JOURNAL OF MANAGEMENT \& PRODUCTION (IJM\&P)

http://www.ijmp.jor.br

v. 12, n. 8, November-December 2021

ISSN: 2236-269X

DOI: 10.14807/ijmp.v12i8.1465

paper is imperative since it can be applied as an opening theme for further research in the area of infectious disease controlling and managing at educational institutions.

\section{REFERENCES}

Abdullah, N. A. M., Zakuan, N., Khayon, M., Ariff, M. S. M., Bazin, N. E. N., \& Saman, M. Z. M. (2012). Adoption of enterprise risk management practices in organization: A Review. Int. J Busi. Inf. Tech., 2(1)

Halim, K. A. (2007). Developing a formal and integrated risk management framework in the higher education sector: A case study on the University of Nottingham (Doctoral dissertation, University of Nottingham).

Beasley, M. S., Clune, R., \& Hermanson, D. R. (2005). Enterprise risk management: An empirical analysis of factors associated with the extent of implementation. Journal of accounting and public policy, 24(6), 521-531.

Chaturvedi, A. (2020, April 4). Hotels open doors in fight against Coronavirus. The Economic Times. https://economictimes.indiatimes.com/industry/services/hotels-/restaurants/hotels-open-doors-in-fight-against-virus/articleshow/74974062.cms?from=mdr

Choudhry, R. M., \& Iqbal, K. (2013). Identification of risk management system in construction industry in Pakistan. Journal of Management in Engineering, 29(1), 42-49.

Colvin, J. W., \& Ashman, M. (2010). Roles, risks, and benefits of peer mentoring relationships in higher education. Mentoring \& Tutoring: Partnership in Learning, 18(2), 121-134.

Deloitte. (2018). Significant risks facing higher education Taking an enterprise approach to risk management. Retrieved May 20, 2020, from https://www.deloitte.com/content/dam/Deloitte/us/Documents/public-sector/us-top-riskshigher-education.pdf

Eells, G. T., \& Rockland-Miller, H. S. (2010). Assessing and responding to disturbed and disturbing students: Understanding the role of administrative teams in institutions of higher education. Journal of College Student Psychotherapy, 25(1), 8-23.

Fraser, J. R., \& Simkins, B. J. (2016). The challenges of and solutions for implementing enterprise risk management. Business horizons, 59(6), 689-698.

Gupta, P. K. (2011). Risk management in Indian companies: EWRM concerns and issues. The Journal of Risk Finance.

Gutiérrez, P. (2020). Coronavirus world map: which countries have the most Covid-19 cases and deaths? Retrieved May 29, 2020, from

https://www.theguardian.com/world/2020/may/28/coronavirus-world-map-which-countrieshave-the-most-covid-19-cases-and-deaths

Harvard Business Review (HBR). (2014). Managing Risks: A New Framework. Retrieved March 12, 2020, from https://hbr.org/2012/06/managing-risks-a-new-framework

Helsloot, I., \& Jong, W. (2006). Risk management in higher education and research in the Netherlands. Journal of Contingencies and Crisis Management, 14(3), 142-159.

Hopkin, P. (2018). Fundamentals of risk management: understanding, evaluating and implementing effective risk management. Kogan Page Publishers. 
Inside Higher Ed (IHE). (2020). Most teaching is going remote. Will that help or hurt online learning? Retrieved April 20, 2020, from https://www.insidehighered.com/digitallearning/article/2020/03/18/most-teaching-going-remote-will-help-or-hurt-online-learning Institute of Risk Management (IRM). (2012). Risk culture: Resources for Practitioners. Retrieved April 24, 2020, from https://www.treasurers.org/ACTmedia/IRM_riskculture_full_Oct12.pdf

Jabbour, M. (2011). The Impact of Enterprise Risk Management on Capital Allocation in Insurance Companies by Mirna Jabbour: SSRN. Retrieved May 16, 2020, from https://papers.ssrn.com/sol3/papers.cfm?abstract_id=1910283

Kinman, G., \& Court, S. (2010). Psychosocial hazards in UK universities: Adopting a risk assessment approach. Higher Education Quarterly, 64(4), 413-428.

Liu, S. L., \& Saif, L. (2020). Emerging viruses without borders: The Wuhan coronavirus. Viruses 2020, 12, 130.

Manab, N., Othman, S., \& Kassim, I. (2012). Enterprise-wide risk management best practices: The critical success factors. OIDA International Journal of Sustainable Development, 4(03), 87-96.

Müller, L. M., \& Goldenberg, G. (2020). Education in times of crisis: The potential implications of school closures for teachers and students.

Mustapha, M., \& Adnan, A. (2015). A case study of Enterprise Risk Management implementation in Malaysian construction companies. International Journal of Economics and Financial Issues, 5(1S).

Nocco, B. W., \& Stulz, R. M. (2006). Enterprise risk management: Theory and practice. Journal of applied corporate finance, 18(4), 8-20.

Tixteco, L. P., Tixteco, M. C. P., Pérez, G. S., Medina, L. K. T., Gómez, J. J. V., \& Tellez, A. C. (2017). Recommendations for Risk Analysis in Higher Education Institutions.

Retrieved May 13, 2020, from

https://www.thinkmind.org/download.php?articleid=securware_2017_7_30_30093

Raanan, Y. (2008). Risk Management in Higher Education: Do We Need it? Risk Management in Higher Education, 1000-1007.

Ruzic-Dimitrijevic, L., \& Dakic, J. (2014). The risk management in higher education institutions. Online Journal of Applied Knowledge Management, 2(1), 137-152.

Safetrac. (2019). Managing risks to reputation in educational institutions. Retrieved May 19, 2020, from https://www.safetrac.com.au/managing-risks-to-reputation-in-educationalinstitutions/

Shafiq, A., \& Nasr, M. (2010). Risk management practices followed by the commercial banks in Pakistan. International Review of Business Research Papers, 6(2), 308-325.

Shewey, J. (2019). The Top 10 Risks Facing Educational Institutions. Retrieved April 30, 2020, from https://www.rcmd.com/resources/blog/top-10-risks-facing-educational-institutions

Toma, S. V., Alexa, I. V., \& Şarpe, D. A. (2014). Identifying the risk in higher education institutions. Procedia Economics and Finance, 15, 342-349.

UNESCO. (2020). Global Education Coalition. Retrieved June 2, 2020, from https://en.unesco.org/covid19/educationresponse/globalcoalition 
DOI: 10.14807/ijmp.v12i8.1465

UNESCO. (2020). Affected Learners from India, retrieved from https://en.unesco.org/covid19/educationresponse on 25 May, 2020.

Unnithan, G. P. S. (2020). Kerala reports first confirmed coronavirus case in India. Retrieved May 11, 2020, from https://www.indiatoday.in/india/story/kerala-reports-firstconfirmed-novel-coronavirus-case-in-india-1641593-2020-01-30

Vergnaud, S. (2020). What Does COVID-19 Stand For? Retrieved April 12, 2020, from https://www.goodrx.com/blog/what-does-covid-19-mean-who-named-it/

Wang, C., Cheng, Z, Yue, X. G., \& McAleer, M. (2020). Risk management of COVID-19 by universities in China.

Wikipedia contributors. (2020). Impact of the COVID-19 pandemic on education Wikipedia. Retrieved June 1, 2020, from https://en.wikipedia.org/wiki/Impact_of_the_COVID-19_pandemic_on_education

World Health Organization (WHO). (2020a). Coronavirus. Retrieved May 10, 2020, from https://www.who.int/health-topics/coronavirus\#tab=tab_1

World Health Organization (WHO). (2020). Novel Coronavirus (2019-nCoV) Situation Report. Retrieved May 10, 2020, from https:/www.who.int/docs/defaultsource/coronaviruse/situation-reports/20200121-sitrep-1-2019-ncov.pdf?sfvrsn=20a99c10_4

World Health Organization (WHO). (n.d.). Naming the coronavirus disease (COVID-19) and the virus that causes it. Retrieved May 10, 2020, from https://www.who.int/emergencies/diseases/novel-coronavirus-2019/technicalguidance/naming-the-coronavirus-disease-(covid-2019)-and-the-virus-that-causes-it

Yaraghi, N., \& Langhe, R. G. (2011). Critical success factors for risk management systems. Journal of Risk Research, 14(5), 551-581.

Yue, X. G., Shao, X. F., Li, R. Y. M., Crabbe, M. J. C., Mi, L., Hu, S., \& Liang, G. (2020). Risk management analysis for novel Coronavirus in Wuhan, China. 